\title{
Üniversite Öğrencilerinin Yeşil Muhasebe Konusundaki Algılart ve Farkındalıkları: Bir Üniversite Örneği
}

\author{
University Students' Perceptions and Awareness on Green Accounting: A Case of \\ University
}

Seyhan ÇIL KOÇYIĞITT *

Sinan TARSUSLU **

\begin{abstract}
$\ddot{o} Z$
Bu çalışmanın amacı üniversite öğrencilerinin yeşil muhasebe konusundaki algı ve farkındalık düzeyini ölçmek ve bu algl ve farkindalık düzeyinin demografik değişsenlerden etkilenip etkilenmediğini belirlemektir. Çalışmaya Erzincan Binali Yıldirım Üniversitesi İktisadi ve İdari Bilimler Fakültesinde eğitim gören 215 "Işsletme" ve "Sağllk Yönetimi" bölüm ögrencileri katılmıştır. Veriler "Kişisel Bilgi Formu" ve "Yeşil Muhasebe Algl ve Farkindalık Ölçeği i" ile toplanmıştır. Yeşil muhasebe algı ve farkındalık ölçeği ortalaması $(\bar{x}=2.30 \pm 0.50)$ olarak tespit edilmişstir. Katılımcların "Yeşil Muhasebe Alglsl" boyut ortalaması ( $\bar{x}=3.11 \pm 0.55)$ "Çevre Bilinci" ( $\bar{x}=2.38 \pm 0.52)$, "Yeşil Muhasebe Ĕgitimi" $(\bar{x}=3.08 \pm 0.75)$ ve "Yeşil Muhasebe Farkindallğ̆ " ( $\bar{x}=2.88 \pm 0.58)$ boyutlarina göre ortalamalarinın daha yüksek olduğu saptanmıştır. Ayrıca ögrrencilerin yeşil muhasebe algl ve farkindalikları ile bölüm, muhasebe alanında staj veya iş tecrübesi, yaş, sinlf, akademik ortalama, mezun olduktan sonra yapmayl düşündü̆g̈ünüz meslek gibi değişkenler arasinda istatistiksel olarak anlamlılık tespit edilmiştir. Sonuç olarak öğrencilerin yeşil muhasebe algı ve farkindalıkları demografik değiş̧kenlere göre işletme bölümü ögrencilerinde, muhasebe alaninda staj veya iş deneyimi olanlarda, 25 ve üstü yaşa sahip, 4. sinff olan, ortalamast 2,51-3,00 ve 3,51-4,00 arasinda ve mezun olduktan sonra mali müşavirlikmuhasebecilik mesleğini seçmeyi düşünen öğrencilerde daha yüksek olduğu belirlenmişstir.
\end{abstract}

\section{ANAHTAR KELIMELER}

Yeşil Muhasebe, Çevre Muhasebesi, Sağllk Yönetimi

\begin{abstract}
The aim of this study is to measure the perception and awareness level of university students about green accounting and to determine whether this perception and awareness level is affected by demographic variables. The study 215 "Business Administration" and "Health Management" students attending Faculty of Economics and Administrative Sciences of Erzincan Binali Ylldirlm participated. The data were collected by "Personal Information Form" and "Green Accounting Perception and Awareness Scale". Green accounting perception and awareness scale average $(\bar{x}=2.30 \pm 0.50)$ was determined. Participants of the "Green Accounting Perception" size average ( $\bar{x}=3.11 \pm 0.55)$ "Environmental Awareness" $(\bar{x}=2.38 \pm 0.52)$, "Green Accounting Education" ( $\bar{x}=3.08 \pm 0.75)$ and "Green Accounting Awareness" $(\bar{x}=2.88 \pm 0.58)$ were found to have higher averages than their size. In addition, students' green accounting perception and awareness, department, accounting internship or work experience, age, class, academic average, after graduation have been determined as statistically significant differences between the variables such as profession. As a result, the students' green accounting perception and awareness according to the demographic variables of the business department students, accounting or work experience in the field of accounting, with 25 years of age and older, the 4th grade is between 2.51 3.00 and 3.51-4.00 and, after graduation, it is determined that students who are considering to choose the profession of financial consultancy-accountancy are higher.
\end{abstract}

KEYWORDS

Green Accounting, Enviromental Accounting, Health Management

\begin{tabular}{|c|c|c|}
\hline \multicolumn{2}{|r|}{$\begin{array}{c}\text { Makale Geliş Tarihi / Submission Date } \\
\text { 05.11.2019 }\end{array}$} & $\begin{array}{c}\text { Makale Kabul Tarihi / Date of Acceptance } \\
\text { 05.03.2020 }\end{array}$ \\
\hline Atıf & $\begin{array}{l}\text { Çil Koçyiğit, S. ve Tarsuslu, S. }(2 \\
\text { Farkındalıkları: Bir Üniversite Örneği. } \\
340 .\end{array}$ & $\begin{array}{l}\text { cilerinin Yeşil Muhasebe Konusundaki Algıları ve } \\
\text { yal Bilimler Meslek Yüksekokulu Dergisi, } 23 \text { (1), 326- }\end{array}$ \\
\hline
\end{tabular}

* Prof. Dr., Ankara Hacı Bayram Veli Üniversitesi, seyhan.cil@hbv.edu.tr, ORCID: 0000-0003-1012-3605

** Öğr. Gör., Erzincan Binalİ Ylldırım Üniversitesi, sinan.tarsuslu@erzincan.edu.tr, ORCID: 0000-0003-0018-1430 


\section{GİRIŞ}

Toplumun üretim ve tüketim kapasitesindeki hızlı artış, sanayi devrimi ile birlikte hızlı endüstrileşme, serbest piyasa ekonomisinin aşırı rekabet koşulları ve buna bağlı olarak sürekli yeni ürün üretme, dünya nüfusunun hızla artması, doğal kaynakların yerine konulamaz şekilde kullanımı, toplumların aşırı tüketime yönlendirilmesi, hava, su ve toprak kirliği, savaşlar ve kazalar sebebiyle çevre sorunları baş göstermiştir. Bu çevre sorunlarının ana aktörleri kimi zaman insanlar, işletmeler ya da devletler olabilmektedir.

Sürdürülebilir bir çevre için öncelikle doğal kaynakların etkin kullanılması gerekmektedir. Doğal kaynakların kullanımı kendini yenileme kapasitesini aşınca çevresel sorunlar ortaya çıkmaktadır. Özellikle 1950'li yıllarda çevre problemleri gündeme gelmeye ve insan yaşamını tehdit eder bir hal almaya başlamıştır (Haftacı ve Soylu 2007:103). Sürdürülebilir ya da etkin kullanılan çevrenin özelliği temiz, yaşanılabilir ve küresel ısınmanın etkilerine en az maruz kalan ortam olarak ifade edilebilir. Etkin bir çevre için öncelikle devletlerin makro politikalar uygulaması ve işletmelerinde eş zamanlı olarak mikro politikalarla bunu desteklemesi gerekmektedir (Bezirci, Özpeynirci ve Duman 2011: 63). İşletmeler de devletle olan ilişkilerinde bu politikaları muhasebe uygulamaları ile gerçekleştirebilmektedir.

$\mathrm{Bu}$ bağlamda işletmelerin çevresel sorunlarının yarattığı ek maliyetleri tespit etmek, muhasebeleştirmek ve kontrol altına alma süreci muhasebenin sosyal sorumluluk kavramı gereği yeşil muhasebeyi ortaya çıkarmıştır. Korukoğlu (2011: 81)'na göre muhasebe açısından çevreyle ilgili ilk çalışmalar 1960'lı yıllarda başladığı ve bu çalışmaların daha çok sosyal muhasebe yönüyle ele alındığı belirtilmiştir. Yeşil muhasebenin ayrı bir başlık olarak ele alınması ise 1980 yılları itibariyle gerçekleşmiştir.

İşletmelerin faaliyetlerini sürdürebilmesi, çevre ile uyumlu üretim yapılması, üretim yapılırken işletmelerin çevreye verdikleri zararın minimuma indirilmesi ve zararın boyutlarının ölçülebilmesi ve önlenebilmesi için yeşil muhasebe uygulamalarına önem verilmesi gerekmektedir. Bu nedenle işletmelerin yönetici kadrolarında bulunan ve bu işletmelerde orta ve alt kademelerde çalışan bireylerin yeşil muhasebe uygulamaları konusunda farkındalık ve bilgi sahibi olmaları önem arz etmektedir.

$\mathrm{Bu}$ nedenle işletmeci, yönetici ya da muhasebeci olmaya aday üniversite öğrencilerinin yeşil muhasebe konusundaki farkındalıklarının ve bilgi düzeylerinin arttırılması gerekmektedir. $\mathrm{Bu}$ çalışmanın amacı gelecekte işletmelerin herhangi bir yönetim pozisyonunda bulunacak öğrencilerin yeşil muhasebe konusundaki farkındalık ve algılarını ölçmek amacıyla yapılmıştır. Bu amaçla Erzincan Binali Yıldırım Üniversitesi İktisadi ve İdari Bilimler Fakültesi İşletme ve Sağllk Yönetimi bölümünde Genel Muhasebe, Finansal Yönetim, Yönetim Muhasebesi, Maliyet Muhasebesi, Şirketler Muhasebesi vb. dersleri alan öğrenciler ile anket yapılmıştır.

Çalışmanın giriş bölümünden hemen sonra yeşil muhasebe konusunda tanımlamalar yapılarak kavramsal çerçeveye yer verilmiş ardından konu ile ilgili hem yerli hem de yabancı alanyazınında yer alan çalışmalar literatür özeti olarak belirtilmiştir. Ardından çalışmanın uygulama bölümüne geçilmiş olup, veriler analiz edilerek yorumlanmış ve sonuç bölümüne geçilmiştir.

\section{KAVRAMSAL ÇERÇEVE}

Günümüz dünyasında küreselleşme ile birlikte çevre sorunlarının hızla artması toplumlarda çevre bilincinin artmasını sağlamıştır. Çevre bilinci artan toplumlar ise işletmelerin çevreye daha duyarlı ürün üretmeleri konusunda beklentilerini de beraberinde getirmiştir. Bu beklentiye paralel olarak dünya ekonomisindeki politikalarda yeşil üretimi bir zorunluluk haline getirmiştir. Yeşil muhasebe, yeşil pazarlama, yeşil üretim ve yeşil yönetim gibi kavramlar firmaların devlete karşı olan sorumluluklarının ayrılmaz bir parçası haline gelmektedir (Bezirci, Özpeynirci ve Duman, 2011: 64).

"Mali nitelikteki işlemleri ve olayları para ile ifade edilmiş şekilde kaydetme, sınıflandırma, özetleyerek rapor etme ve sonuçları yorumlama bilim ve sanatı" (Sevilengül, 2005: 9) olarak tanımlanan muhasebe çevrenin artan önemini de göz önünde bulundurarak yeşil muhasebe uygulamalarını kullanmaya başlamıştır.

Çevre muhasebesinin temel aldığ felsefe, Kuzey Amerika yerlilerinin doğal çevrenin önemini çok çarpıc1 olarak ifade eden, "Bu dünya bize atalarımızdan miras kalmadı, biz onu çocuklarımızdan ödünç aldık" atasözü ve benzeri görüşlere dayanmaktadır (Özkol, 1998: 18).

Yeşil muhasebe konusunda alanyazını incelendiğinde yeşil muhasebenin genellikle çevre muhasebesi olarak ele alındığı görülmüştür. Çevre muhasebesi;

- Schaltegger and Burritt (2006) tarafından; "çevresel bir faaliyetin ekonomik etkilerinin ya da çevresel problemlerinin açıklanması, incelenmesi, kaydedilmesini kapsayan faaliyetler bütünü" (Antepli ve Aslan, 2018: 1460), 
- Gray ve Bebbington (1993) tarafından "finansal muhasebede ölçümleme işlevlerini örneği finansal raporlama, işletme içi ve işletme dışı çevre faktörlerinin dikkatle uygulanması" (Alagöz ve Yılmaz, 2001: 150) olarak tanımlanmıştır.

- Çevre muhasebesi; "doğada hazır halde bulunan kaynakların kullanılması sonucunda, işletmelerin bu kullanımla katlanacakları maliyetlerin ve elde edecekleri faydaların belirlenmesine yardımcı olan bilim dalıdır" (Bengü ve Can, 2009: 156-157).

- Çevre muhasebesi; "çevresel kaynakların kullanımı sonucu doğacak etkilerin muhasebesidir" (Özbirecikli ve Melek, 2002: 82).

$\mathrm{Bu}$ tanımlamalardan yola çıkarak Yılmaz ve Şahin (2017: 112) ise çevre muhasebesini, işletmelerin çevreyle ilgili uygulayacağı muhasebe politikaları ve bu politikalar sonucunda ortaya çıkan maliyetler olarak tanımlarken yeşil muhasebeyi ise küresel iklim değişikliğini önlemek için yapılan eylemler olarak ifade etmişlerdir. Kırlığlu ve Can (2006: 3) ise çevre muhasebesinin daha çok parasal göstergelere odaklandığını ve ekonomik temellerden ötürü parasallaştırma konusunun ön planda olduğunu belirtirken yeşil muhasebenin ise fiziksel (sayısal) göstergelere odaklandığını ve bu muhasebe türünün ekolojik temellere dayandığı için ve birçok durumda çevresel kalemler parasallaştıralamadığ için fiziki (miktar) bilgilerin parasal bilgilerden çok daha önemli olduğunu ifade etmişlerdir. Bunun yanında çevre muhasebesi, muhasebe, muhasebeciler ve ekoloji arasındaki karşılıklı ilişkilerin incelenmesi çabalarına verilen ortak bir isim olarakta ifade edilebilir (Clark ve O’Neill, 2005: 117).

Son olarak ta yeşil muhasebe ya da çevre muhasebesinin, muhasebe sistemi içerisinde ayrı bir muhasebe türü olmadığını söylemek gerekmektedir. Çevre muhasebesi günümüz dünyasında çevrenin artan önemi nedeniyle, muhasebe sistemi içerisinde çevresel maliyetlerin hesaplanması, raporlanması ve kayıt edilmesi sürecidir (Haftacı ve Soylu, 2007: 119).

\section{LITERATÜR ÖZETİ}

Literatür incelendiğinde yeşil muhasebe konusunda ulusal ve uluslararası yayınlarda birçok çalışmaya rastlanmıştır.

Uluslararası literatürde karşılaşılan çalışmalar aşağıdaki gibidir:

Vincent (2000) tarafindan yazılan "Yeşil Muhasebe: Teoriden Pratiğe" adlı çalışmada yeşil muhasebe konusu teorik olarak incelenmiş ve kurduğu model ile ülkelerin yeşil muhasebe konusundaki gelecekleri açıklanmaya çalışılmıştır.

Cairns (2001)'de yapmış olduğu çalışmada ticari bir kaynak olarak kullanılan ormanların ve değeri belirlenmemiş doğal kaynakların ulusal muhasebe açısından marjinal değerini açıklanmıştır. Yazara ait diğer bir çalışmada (2004) yenilenebilir ve yenilenemez enerji kaynakları için yeşil muhasebe ilkeleri belirlenmeye çalışılmıştır. Cairns'e ait (2009) diğer bir çalışmada da petrol endüstrisi açısından yeşil muhasebe uygulamaları açıklanmıştır.

Halberg ve diğerleri (2005) tarafından yapılan bir çalışmada sekiz Avrupa ülkesinde bulunan çiftlikler incelenmiş ve yeşil muhasebenin çevresel göstergeler açısından kullanılabileceği sonucuna ulaşılmıştır.

Fleischman ve Schuele (2006) tarafından yapılan çalışmada öğrencilere yeşil muhasebe konusunda verilen eğitimlerin, öğrencilerin çevresel konularla ilgili farkındalıklarını arttırdığı belirlenmiştir.

Jahamani (2003) Ürdün ve Birleşik Arap Emirlikleri’nde iki şirketi temel alarak yaptığı çalışmada şirketlerin, çevresel sorunların farkında olduğunu fakat çevreyi koruma konusundaki taahhütlerinin düşük olduğunu tespit etmiştir.

Aronsson ve Löfgren (1998) tarafindan yazılan "Kusurlu Piyasa Ekonomilerinde Yeşil Muhasebe" adlı çalışmada kusurlu ya da eksik piyasa ekonomisine sahip sistemlerde yeşil muhasebe işleyişi incelenmiş ve sosyal muhasebe araştırmaları özetlenmiştir.

Yeşil muhasebe ile ilgili ulusal alanyazını incelendiğinde; yeşil muhasebe ile çevre muhasebesi ayrımının çok fazla yapılmadığı ve birbirlerinin yerine kullanıldığı görülmüştür. Ulusal litertürde yeşil muhasebe ve çevre muhasebesi ile ilgili karşılaşılan çalışmaların bazıları şu şekildedir:

Aslanertik ve Özgen (2007) tarafindan yapılan çalışmada çevresel muhasebenin farklı boyutlarına yoğunlaşılmış ve turizm sektörü açısından önemi açıklanmıştır. Aktürk ve arkadaşları (2011) ise çalışmada muhasebe standartları (TMS/TFRS) bağlamında otel işletmelerinde çevre muhasebesi ve çevre duyarlılı̆̆ına ilişkin finansal gelişmelerin raporlara yansıtılması ve bu bilgilerin toplum ile paylaşılmasının önemini ifade etmişlerdir.

Memiş (2009) "İ̧letme Yönetim Aracı Olarak Çevresel Muhasebe" adlı çalışmasında çevresel yönetim sistemleri, çevresel maliyet ve çevresel yönetim muhasebesi konuları işletmeler açısından incelenmiştir.

Selçuk Üniversitesi Sosyal Bilimler Meslek Yüksekokulu Dergisi, Yıl: 2020 Cilt: 23 Sayı:1 
Kurşunel ve arkadaşları (2006) Konya ilinde bulunan muhasebe meslek mensuplarının çevre muhasebesi konusundaki bilgi ve düşüncelerini araştırmışlardır. Sonuç olarak muhasebe meslek mensuplarının yarıya yakınının çevre muhasebesi konusunda herhangi bir bilgiye sahip olmadığını tespit etmişlerdir.

Korukoğlu (2011) İzmir ilinde farklı sektörlerde faaliyet gösteren işletmelere çevre muhasebesi ve diğer çevresel faaliyetlerin işletmelerde gerçekleşme durumu hakkında anket yapılmış. Sonuç olarak işletme maliyetlerinin daha ayrıntılı izlenebilmesi için çevre muhasebesinin önemli olduğu belirlenmiştir.

Esmeray ve Güngör Tanç (2009) Kayseri ilinde faaliyet gösteren bir sanayi işletmesinde Faaliyete Dayalı Maliyetleme (FDM) yöntemi ve Analitik Hiyerarşi Prosesi (AHP) entegrasyon yöntemlerini kullanarak yaptıkları çalışmada; işletmelerin yoğun çevresel önlem alması ve çevresel maliyetlerin artması nedeniyle mamullerin doğru bir şekilde maliyetlendirilmesi ve bu bilgilere göre karar alternatiflerinin oluşturulması işletmelerin rekabet edebilme potansiyelini arttırdığını tespit etmişlerdir.

\section{ARAŞTIRMANIN METODOLOJISI}

\subsection{Araştırmanın Amacı ve Önemi}

Ülkemizde iktisadi ve idari bilimler fakültelerinin birçok bölümünde olduğu gibi işletme ve sağllk yönetimi bölümlerinde muhasebe, yönetim muhasebesi, finansal yönetim, maliyet muhasebesi vb. dersleri verilmektedir. Bu bölümlerde eğitim gören öğrencilerin birer işletmeci ya da yönetici olacağı ve bu açıdan işletmelerinin faaliyetlerini sürdürürken çevreye verecekleri zararın farkında olmaları açısından eğitim süreçlerinde yeşil muhasebe konusunu öğrenmeleri gerekmektedir. Bu sebeple çalışmanın amacı Erzincan Binali Yıldırım Üniversitesi (EBYÜ) İktisadi ve İdari Bilimler Fakültesinde (İ̈BF) eğitim gören işletme ve sağlık yönetimi bölümü lisans öğrencilerinin yeşil muhasebe konusundaki algıları ve farkındalıklarını belirlemek amaciyla yapılmışıtır.

Öğrencilerin yeşil muhasebe konusundaki algıları ve farkındalıkları ile ilgili çalışmalar incelendiğinde, işletme ve sağlik yönetimi bölümünde eğitim gören öğrenciler üzerinde herhangi bir çalışmaya rastlanmamıştır. $\mathrm{Bu}$ açıdan işletme ve sağlık yönetimi bölümü öğrencilerinin yeşil muhasebe konusundaki alg1 ve farkındalıklarını tespit etmek açısından çalışmamız önem arz etmektedir.

\subsection{Araştırmanın Sınırlılıkları, Varsayımları ve İzinleri}

Araştırma Nisan-Mayıs 2018 dönemi içerisinde Erzincan Binali Yıldırım Üniversitesi İ̈BF İşletme ve Sağlık Yönetimi bölümünde eğitim gören öğrenciler üzerinde yapılmıştır. Çalışma konusu kapsamında karşılaştırma ve genelleme yapabilmek için başka üniversitelerde eğitim gören öğrenciler üzerinde de yapılmasına ihtiyaç vardır. Örneklem büyüklüğü hesaplandıktan sonra anketlerin değerlendirilmesi sırasında eksik, hatalı veya tüm sorulara aynı seçenekte cevap verilmesi gibi anketler değerlendirme dışı bırakılmıştır.

Araştırmaya gönüllü öğrenciler dâhil edilmiştir. Anket sorunlarına verilecek cevaplar öğrencilerin görüşlerine dayandığı varsayılmaktadır. Örnekleme girecek olan işletme ve sağlık yönetimi bölümü öğrencileri evreni temsil edecek şekilde seçilmiştir. Ayrıca bu çalışmanın, bundan sonraki yeşil muhasebe konusunda yapılacak olan çalışmalara da kılavuzluk (Yeşil muhasebe algısı konusundaki) edeceği düşünülmektedir.

\subsection{Araştırmanın Evreni ve Örneklemi}

Araştırmanın evrenini Erzincan ilinde bulunan EBYÜ İ̈BF İşletme ve Sağlık Yönetimi bölümü lisans programında eğitim gören öğrenciler oluşturmaktadır. Araştırmanın yapıldı̆̆ 1 tarihlerde sağlık yönetimi bölümünde 4. Sınıf öğrencileri bulunmadığından çalışma İşletme 1. 2. 3. ve 4. sınıf ile Sağlık Yönetimi 1. 2. ve 3. sınıfta okuyan öğrencileri kapsamaktadır. Çalışmanın evrenini İ̈BF öğrenci işleri birimi tarafından verilen 483 öğrenci oluşturmakta olup bu evrenden 297 adet kullanılabilir anket verisi elde edilmiştir. Bölüm bazında işletme bölümü evrenini 211 öğrenci oluşturmakta olup bu evrenden 114 tane kullanılabilir anket elde edilmiştir. Sağlık Yönetimi bölümü için evreni 272 öğrenci oluşturmakta olup be evrenden 183 tane kullanılabilir anket elde edilmiştir. 
Tablo 1 Öğrenci Sayıları (Evren ve Örneklem)

\begin{tabular}{rlcccccc}
\hline \multicolumn{2}{r}{ Öğrenciler } & \multicolumn{2}{c}{ Sağlık Yönetimi } & \multicolumn{2}{c}{ İşletme } & \multicolumn{2}{c}{ Toplam } \\
\hline & & Evren & Örneklem & Evren & Örneklem & Evren & Örneklem \\
1. & Sinıf & 89 & 58 & 56 & 30 & 145 & 88 \\
2. & Sinıf & 102 & 81 & 43 & 28 & 150 & 109 \\
3. & Sinıf & 81 & 44 & 38 & 17 & 119 & 61 \\
4. & Sinıf & - & - & 74 & 39 & 74 & 39 \\
Toplam & 272 & 183 & 211 & 114 & 483 & 297 \\
\hline
\end{tabular}

Tablo 1'den yola çıkarak örneklemin yeterli olup olmadığı konusunda aşağıdaki formülden yararlanılmıştır.

$$
n=\frac{\mathrm{N}(\mathrm{tl}-\mathrm{a})^{2} \cdot(\mathrm{p} \cdot \mathrm{q})}{\mathrm{S}^{2} \cdot(N-1)+S^{2} \cdot(p \cdot q)}
$$

Evrenin büyüklüğünün bilindiği durumlarda örnekleme alınacak öğrenci sayısının belirlenebilmesi amacıyla kullanılan yukarıdaki formülde (K1lıç, 2012:141) ana kütle büyüklüğü N=483, \%95 güven aralığ1 $(\alpha=0.05)$ ve $\mathrm{t}=1.96$ kabul edilebilir örneklem hatası ile gerekli örneklem sayısının 215 olduğu tespit edilmiştir.

\subsection{Araştırmanın Yöntemi}

Araştırmada veri toplama aracı olarak anket yöntemi kullanılmıştır. Anket formu iki bölümden oluşmaktadır. Birinci bölüm demografik özellikleri belirlemeye yönelik toplamda 9 (cinsiyet, yaş, bölüm, öğrenim türü, sınıf, akademik ortalama, muhasebe alanında staj ya da iş deneyimi, alınan muhasebe ders türleri ve mezun olduktan sonra yapmayı düşünülen meslek) ifadeden oluşmaktadır. İkinci bölümde ise öğrencilerin yeşil muhasebe konusundaki algı ve farkındalıklarını ölçmek için Yılmaz ve Şahin'in (2017) "Muhasebe Dersi Alan Öğrencilerin Yeşil Muhasebe Konusundaki Algıları ve Farkındalıkları” adlı çalışmasında yer alan anket soruları (ya soru ya ifade) kullanılmıştır. Ölçekte 4'lü likert yöntemi kullanılarak katılımcılara toplamda 25 ifade yöneltilmiştir. Katılımcılardan "kesinlikle katılmıyorum: 1", "katılmıyorum: 2", "katılıyorum: 3" ve "kesinlikle katılıyorum: 4" şeklinde anket sorularına cevap vermeleri istenmiştir. Ayrıca ölçek yeşil muhasebe algisı $(7,8,11,14,15,17,19,20,21,23)$, çevre bilinci $(1,2,3,5)$, yeşil muhasebe eğitimi $(24,25)$ ve yeşil muhasebe farkındalığı $(10,22)$ adlı dört boyuttan oluşmaktadır (Yılmaz ve Şahin, 2017: 114-115).

Çalışmaya katılan işletme ve sağlık yönetimi bölümü öğrencilerinin almış oldukları muhasebe dersleri de incelenerek bölüm bazında seçmeli ve zorunlu olarak sınıflandırılmıştır. Tablodan yola çıkarak hem işletme hem de sağlık yönetimi bölümü öğrencilerinin yoğun bir şekilde muhasebe dersleri aldıkları tespit edilmiştir. Her iki bölümde de Genel Muhasebe, Finansal Yönetim, Maliyet Muhasebesi, Yönetim Muhasebesi ve Şirketler Muhasebesi dersleri zorunlu/seçmeli olarak verilmiştir.

Tablo 2 İşletme ve Sağlık Yönetimi Bölümü Muhasebe Dersleri

\begin{tabular}{|c|c|c|c|c|c|}
\hline \multicolumn{3}{|c|}{ İşletme } & \multicolumn{3}{|c|}{ Sağlık Yönetimi } \\
\hline Sınıf/Dönem & & $\begin{array}{l}\text { Zorunlu/ } \\
\text { Seçmeli }\end{array}$ & Sınıf/Dönem & & $\begin{array}{c}\text { Zorunlu/ } \\
\text { Seçmeli }\end{array}$ \\
\hline 1. sınıf 1. dönem & Muhasebe I & Zorunlu & 1. sınıf- 1. dönem & $\begin{array}{l}\text { Sağlık İşletmelerinde } \\
\text { Genel Muhasebe I }\end{array}$ & Zorunlu \\
\hline 1. sinıf 2. dönem & Muhasebe II & Zorunlu & 1. sinıf- 2. dönem & $\begin{array}{l}\text { Sağlık İşletmelerinde } \\
\text { Genel Muhasebe II }\end{array}$ & Zorunlu \\
\hline 2. sinıf 1. dönem & Finansman & Zorunlu & 2. sinıf- 1. dönem & $\begin{array}{l}\text { Sağlık İşletmelerinde } \\
\text { Finansal Yönetim I }\end{array}$ & Zorunlu \\
\hline 2. sınıf 2. dönem & Finansal Yönetim & Zorunlu & 2. sınıf- 2. dönem & $\begin{array}{l}\text { Sağlık İşletmelerinde } \\
\text { Finansal Yönetim II }\end{array}$ & Zorunlu \\
\hline 3. sınıf 1. dönem & $\begin{array}{l}\text { Maliyet } \\
\text { Muhasebesi I }\end{array}$ & Zorunlu & 3. sınıf -2. dönem & $\begin{array}{l}\text { Sağlık İşletmelerinde } \\
\text { Yönetim Muhasebesi }\end{array}$ & Zorunlu \\
\hline 3. sınıf 2. dönem & $\begin{array}{l}\text { Maliyet } \\
\text { Muhasebesi II }\end{array}$ & Zorunlu & 4. sınıf -2. dönem & $\begin{array}{l}\text { Sağlık İşletmelerinde } \\
\text { Muhasebe Denetimi }\end{array}$ & Zorunlu \\
\hline 4. sınıf 1. dönem & $\begin{array}{l}\text { Mali Tablolar } \\
\text { Analizi }\end{array}$ & Zorunlu & 3. sınıf- 1. dönem & $\begin{array}{l}\text { Sağlık İşletmelerinde } \\
\text { Maliyet Muhasebesi }\end{array}$ & Seçmeli \\
\hline 2. sınıf 1. dönem & $\begin{array}{l}\text { Şirketler } \\
\text { Muhasebesi }\end{array}$ & Seçmeli & 2. sinıf -2. dönem & $\begin{array}{l}\text { Sağlık İşletmelerinde } \\
\text { Şirketler Muhasebesi }\end{array}$ & Seçmeli \\
\hline 2. sınıf 2. dönem & $\begin{array}{l}\text { Muhasebe } \\
\text { Uygulamaları }\end{array}$ & Seçmeli & & & \\
\hline
\end{tabular}




\begin{tabular}{lll}
\hline 4. sınıf 1. dönem & Muhasebe Denetimi & Seçmeli \\
4. sınıf 1. dönem & Yönetim & Seçmeli \\
& Muhasebesi & \\
\hline
\end{tabular}

Çalışmamızda kullanılan ölçek için güvenirlik analizi yapılmıştır. Güvenirlik analizi sonucunda 25 ifadeden oluşan Muhasebe Dersi Alan Öğrencilerin Yeşil Muhasebe Konusundaki Algıları ve Farkındalıkları anketinin yüksek derecede güvenilir $(\alpha=0,913)$ olduğu tespit edilmiştir. Ayrı ölçek boyutları için güvenirlik analizi sonucuna bakıldığında yeşil muhasebe algısı boyutu için $(\alpha=0,881)$ çevre bilinci boyutu $(\alpha=0,773)$, yeşil muhasebe eğitimi $(\alpha=0,670)$ ve son olarak yeşil muhasebe farkındalığ boyut için de $(\alpha=0,421)$ olduğu belirlenmiştir.

Tablo 3 Güvenirlik Analizi

\begin{tabular}{lcc}
\hline & Güvenirlik Analizi (Cronbach's Alpha Değeri) \\
\hline & & Yılmaz ve Şahin (2017) \\
Yeşil Muhasebe Algısı & 0,881 & 0,931 \\
Çevre Bilinci & 0,773 & 0,816 \\
Yeşil Muhasebe Eğitimi & 0,670 & 0,627 \\
Yeşil Muhasebe Farkındalığı & 0,421 & 0,504 \\
Toplam Ölçek & $\mathbf{0 , 9 1 3}$ & 0,888 \\
\hline
\end{tabular}

Elde edilen veriler elektronik ortama aktarılıp analiz edilmiştir. Önemlilik düzeyi $\mathrm{p}<0.05$ olarak alınmıştır. Verilerin analizinde Kişisel Bilgi Formundaki verileri analiz etmek için öncelikle frekans analizi ve yüzde dağılımları hesaplanmıştır. Ayrıca öğrencilerin ankette yer alan ifadelere katılma derecelerine ilişkin olarak, ortalama puanı, standart sapması ve medyan değerleri hesaplanmıştır. Örneklem verilerinin normal dağılıma uygunluk gösterip göstermediğini belirlemek için Kolmogorow Smirnow ve Shapiro Wilk testi yapılmıştır. Yapılan normallik testi sonucu ölçek verilerinin normal dağılmadığı $(\mathrm{z}=0,940 ; \mathrm{p}<0,005)$ saptanmıştır. Bu sebeple ölçeğin birinci bölümündeki demografik özellikler ile (cinsiyet, yaş, bölüm, öğrenim türü, sınıf, akademik ortalama, muhasebe alanında staj ya da iş deneyimi, alınan muhasebe ders türleri ve mezun olduktan sonra yapmayı düşünülen meslek) yeşil muhasebe algısı ölçeği arasındaki farklılığın anlamlı olup olmadığını belirlemek için iki seçenekli ifadelerde Mann Whitney U Testi, ikiden fazla seçenekli ifadelerde Kruskal Wallis H Testi uygulanmıştır. Son olarak ikiden fazla seçenekli ifadelerde anlamlılığın nedenini tespit etmek amacıyla ileri analizlerden Tamhane T2 testi de kullanılmıştır.

\subsection{Araştırmanın Hipotezleri}

$\mathbf{H}_{1}$ : İşletme bölümü öğrencilerinin yeşil muhasebe konusundaki algıları ve farkındalıkları ile Sağlik Yönetimi bölümü öğrencilerinin algıları ve farkındalıkları arasında anlamlı bir farklılık vardır.

$\mathbf{H}_{2}$ : Cinsiyet ile ögrencilerin yeşil muhasebe konusundaki algıları ve farkındalıkları arasında anlamlı bir farkl11.k vardir.

$\mathbf{H}_{3}$ : Yaş değişkeni ile öğrencilerin yeşil muhasebe konusundaki algıları ve farkındalıkları arasında anlamlı bir farklılık vardır.

$\mathbf{H}_{4}$ : Öğrenim türü değişkeni ile öğrencilerin yeşil muhasebe konusundaki algıları ve farkındalıkları arasında anlamlı bir farklılık vardır.

$\mathbf{H}_{5}$ : Sınıf değişkeni ile öğrencilerin yeşil muhasebe konusundaki algıları ve farkındalıkları arasında anlamlı bir farklılık vardır.

$\mathbf{H}_{\mathbf{6}}$ : Akademik ortalama değişkeni ile öğrencilerin yeşil muhasebe konusundaki algıları ve farkındalıkları arasında anlamlı bir farklılık vardır.

$\mathbf{H}_{7}$ : Muhasebe alanında staj ya da iş deneyimi değişkeni ile öğrencilerin yeşil muhasebe konusundaki algıları ve farkındalıkları arasında anlamlı bir farklılık vardır.

$\mathbf{H}_{\mathbf{8}}$ : Alınan muhasebe ders türü değişkeni ile öğrencilerin yeşil muhasebe konusundaki algıları ve farkındalıkları arasında anlamlı bir farklılık vardır.

$\mathbf{H}_{\mathbf{9}}$ : Mezun olduktan sonra yapmayı düşünülen meslek değişkeni ile öğrencilerin yeşil muhasebe konusundaki algıları ve farkındalıkları arasında anlamlı bir farklılık vardır. 


\section{BULGULAR VE YORUM}

Ölçek verilerinin analizinde öncelikle demografik verilerin tanımlayıcı istatistiklerine (frekans, yüzde ve ortalama) yer verilmiştir.

Tablo 4 Demografik Verilerin Analizi

\begin{tabular}{|c|c|c|c|}
\hline Demografik veriler & $\mathbf{n}$ & $\%$ & $\bar{X}$ \\
\hline Cinsiyet: & 297 & 100 & \\
\hline Erkek & 122 & 41.1 & \\
\hline Bayan & 175 & 58.9 & \\
\hline Yaş: & 297 & 100 & \\
\hline 20 ve Altı & 102 & 34.3 & $21.50 \pm 1.89$ \\
\hline 21-24 Arası & 171 & 57.6 & \\
\hline 25 ve Üstü & 24 & 8.1 & \\
\hline Bölüm: & 297 & 100 & \\
\hline Sağlık Yönetimi & 183 & 61.6 & \\
\hline İşletme & 114 & 38.4 & \\
\hline Öğrenim Türü: & 297 & 100 & \\
\hline Normal Öğretim & 155 & 52.2 & \\
\hline İkinci Öğretim & 142 & 47.8 & \\
\hline Sinıf: & 297 & 100 & \\
\hline 1.Sinıf & 88 & 29.6 & \\
\hline 2.Sinıf & 109 & 36.7 & \\
\hline 3.Sinıf & 61 & 20.5 & \\
\hline 4.Sinıf & 39 & 13.1 & \\
\hline 5 ve Üstü & - & - & \\
\hline Akademik Ortalama: & 297 & 100 & \\
\hline $1,00-1,50$ & 14 & 4.7 & \\
\hline $1,51-2,00$ & 61 & 20.3 & \\
\hline $2,01-2,50$ & 89 & 30.2 & $2.49 \pm 0.55$ \\
\hline 2,51-3,00 & 81 & 27 & \\
\hline $3,01-3,50$ & 38 & 13 & \\
\hline $3,51-4,00$ & 14 & 4.7 & \\
\hline \multicolumn{4}{|l|}{ Muhasebe Alanında Staj veya } \\
\hline İş Tecrübesi: & 297 & 100 & \\
\hline Evet & 90 & 30.3 & \\
\hline Hayır & 207 & 69.7 & \\
\hline *Aldığınız Muhasebe Dersi: & 297 & 100 & \\
\hline Genel Muhasebe & 297 & 100 & \\
\hline Yönetim Muhasebesi & 102 & 34.4 & \\
\hline Finansal Yönetim & 209 & 70.3 & \\
\hline Maliyet Muhasebesi & 102 & 34.4 & \\
\hline Diğer & 127 & 42.7 & \\
\hline \multicolumn{4}{|c|}{$\begin{array}{llll}\text { Mezun } & \text { Olduktan } & \text { Sonra } & \text { Yapmayı }\end{array}$} \\
\hline Düşündüğünüz Meslek: & 297 & 100 & \\
\hline Akademisyenlik & 52 & 17.5 & \\
\hline Mali Müşavirlik-Muhasebecilik & 37 & 12.5 & \\
\hline Bankacılık & 16 & 5.4 & \\
\hline Özel Sektörde İdari Görev & 72 & 24.2 & \\
\hline Devlet Kurumlarında Uzmanlık & 35 & 11.8 & \\
\hline Memurluk & 40 & 13.5 & \\
\hline Diğer & 45 & 15.2 & \\
\hline
\end{tabular}

Araştırmaya katılan işletme ve sağlı yönetimi bölümü öğrencileri demografik durumlarına göre incelendiğinde katılımcıların 175 'i (\%58.9) bayan, 171'i (\%57.6) 21-24 yaş arasında olup yaş ortalaması $21.50 \pm 1.89$ olarak tespit edilmiştir. Katılımcıların 183 'ü (\%61.6) sağlık yönetimi bölümünde, 155'i (\%52.2) normal öğretimde ve 109'u (\%36.7) 2. Sinıfta eğitim gördügü belirlenmiştir. Öğrencilerin 4'lük sisteme göre akademik not ortalamaları incelendiğinde 89'u (\%30.2) 2.01-2.50 arasında olduğu ve not ortalamasının $2.49 \pm 0.55$ olduğu tespit edildi. Katılımcılara "Muhasebe alanında staj veya iş tecrübesi var mı?” şeklinde soru 
sorulduğunda 207'si (\%69.7) hayır cevabını verdiği belirlendi. Ayrıca fakülte eğitimleri boyunca aldıkları muhasebe dersleri sorulduğunda tüm katılımcıların 297 (\%100) genel muhasebe dersi aldığı, 209 (\%70.3) katılımcının ise finansal yönetim dersi aldığı ve 102'şer (\%34.4) katılımcının da yönetim muhasebesi-maliyet muhasebesi dersleri aldığı son olarak da $127(\% 42.7)$ katılımcının diğer muhasebe derslerini aldığı (şirketler muhasebesi, mali tablolar analizi, muhasebe denetimi, finansman) tespit edilmiştir. Son olarak katılımcılara "Mezun olduktan sonra yapmayı düşündüğünüz meslek" sorulduğunda katılımcıların 72'si (\%24.2) "özel sektörde idari görev", 16’s1 (\%5.4) bankacıllı yapmak istediğini belirtmiştir. 
Tablo 5 Yeșil Muhasebe İfadelerinin Tanımlayıcı İstatiskleri

\begin{tabular}{|c|c|c|c|c|c|c|c|c|c|c|c|}
\hline \multirow[t]{2}{*}{ Ölçek Soruları } & \multicolumn{2}{|c|}{$\begin{array}{c}\text { Kesinlikle } \\
\text { Katılmıyorum }\end{array}$} & \multicolumn{2}{|c|}{ Katılmıyorum } & \multicolumn{2}{|c|}{ Katılıyorum } & \multicolumn{2}{|c|}{$\begin{array}{c}\text { Kesinlikle } \\
\text { Katılıyorum }\end{array}$} & \multirow[t]{2}{*}{$\overline{\bar{X}}$} & \multirow[t]{2}{*}{$\mathbf{S . S}$} & \multirow[t]{2}{*}{$\begin{array}{c}\text { Med- } \\
\text { yan }\end{array}$} \\
\hline & $\mathbf{N}$ & $\%$ & $\mathbf{N}$ & $\%$ & $\mathbf{N}$ & $\%$ & $\mathbf{N}$ & $\%$ & & & \\
\hline $\begin{array}{l}\text { 1.Çevresel problemlerle ilgili yenilik ve gelişmeleri güncel olarak takip } \\
\text { ederim. }\end{array}$ & 15 & 5.1 & 65 & 21.9 & 142 & 47.8 & 75 & 25.3 & 2.93 & 0.81 & 3.00 \\
\hline 2.Yeşil muhasebenin ne olduğu konusunda hiçbir bilgi sahibi değilim. & 87 & 29.3 & 109 & 36.7 & 52 & 17.5 & 49 & 16.5 & 2.21 & 1.04 & 2.00 \\
\hline 3.Yeşil muhasebe kavramını sadece isim olarak biliyorum. & 98 & 33 & 110 & 37 & 59 & 19.9 & 30 & 10.1 & 2.07 & 0.96 & 2.00 \\
\hline $\begin{array}{l}\text { 4.Yeşil muhasebe kavramını makale, kitap, internet vb. kaynaklardan } \\
\text { duydum. }\end{array}$ & 84 & 28.3 & 56 & 18.9 & 99 & 33.3 & 58 & 19.5 & 2.44 & 1.09 & 3.00 \\
\hline 5.Eğitimim sırasında yeşil muhasebe ile ilgili ders aldım. & 109 & 36.7 & 56 & 18.9 & 62 & 20.9 & 70 & 23.6 & 2.31 & 1.19 & 2.00 \\
\hline $\begin{array}{l}\text { 6.Yeşil muhasebe uygulamalarının enerji tasarrufunu arttıracağına } \\
\text { inanıyorum. }\end{array}$ & 29 & 9.8 & 35 & 11.8 & 138 & 46.5 & 95 & 32 & 3.00 & 0.91 & 3.00 \\
\hline $\begin{array}{l}\text { 7.Yeşil muhasebe uygulamalarının su kullanımı ve yönetiminde yararlı } \\
\text { olacağına inanıyorum. }\end{array}$ & 20 & 6.7 & 37 & 12.5 & 125 & 42.1 & 115 & 38.7 & 3.12 & 0.87 & 3.00 \\
\hline $\begin{array}{l}\text { 8. Yeşil muhasebe uygulamalarının sera gazı salınımını }\left(\mathrm{CO}_{2}\right) \text { yönetmekte } \\
\text { yararlı olacağına inanıyorum. }\end{array}$ & 18 & 6.1 & 49 & 16.5 & 147 & 49.5 & 83 & 27.9 & 2.99 & 0.83 & 3.00 \\
\hline $\begin{array}{l}\text { 9. Yeşil muhasebe uygulamalarının üretim sırasında ortaya çıkan atıkların } \\
\text { yönetiminde yararlı olacağına inanıyorum. }\end{array}$ & 18 & 6.1 & 19 & 6.4 & 164 & 55.2 & 96 & 32.3 & 3.13 & 0.78 & 3.00 \\
\hline $\begin{array}{l}\text { 10.Yeşil muhasebe uygulamalarının biyoçeşitliliğin sürdürülmesinde yararlı } \\
\text { olacağına inanıyorum. }\end{array}$ & 17 & 5.7 & 29 & 9.8 & 168 & 56.6 & 83 & 27.9 & 3.06 & 0.77 & 3.00 \\
\hline $\begin{array}{l}\text { 11.Yeşil muhasebe uygulamalarının doğal kaynakların gereksiz tüketiminin } \\
\text { sınırlandırılmasında yararlı olacağına inanıyorum. }\end{array}$ & 19 & 6.4 & 23 & 7.7 & 130 & 43.8 & 125 & 42.1 & 3.21 & 0.84 & 3.00 \\
\hline $\begin{array}{l}\text { 12.Çevresel problemlerin çözümü için işletmelerin yeşil muhasebe } \\
\text { uygulamalarını yürütmeleri gereklidir. }\end{array}$ & 18 & 6.1 & 50 & 16.8 & 143 & 48.1 & 86 & 29 & 3.00 & 0.83 & 3.00 \\
\hline $\begin{array}{l}\text { 13.Yeşil muhasebe uygulamalarının temiz ve güvenli üretimi arttıracağına } \\
\text { inanıyorum. }\end{array}$ & 16 & 5.4 & 27 & 9.1 & 122 & 44.1 & 132 & 44.4 & 3.24 & 0.83 & 3.00 \\
\hline $\begin{array}{l}\text { 14.Yeşil muhasebe uygulamalarının ekosistemi koruyucu olduğuna } \\
\text { inanıorum. }\end{array}$ & 18 & 6.1 & 21 & 7.1 & 162 & 54.5 & 96 & 32.3 & 3.13 & 0.78 & 3.00 \\
\hline $\begin{array}{l}\text { 15.İşletmeler yeşil muhasebe uygulamalarının bir parçası olarak çevre } \\
\text { politikalarını belirlemelidir. }\end{array}$ & 18 & 6.1 & 35 & 11.8 & 116 & 39.1 & 128 & 43.1 & 3.19 & 0.87 & 3.00 \\
\hline $\begin{array}{l}\text { 16.Çevreye duyarlı ürünle üretme konusunda işletmeler finansal olarak } \\
\text { desteklenmelidir. }\end{array}$ & 19 & 6.4 & 26 & 8.8 & 141 & 47.5 & 111 & 37.4 & 3.15 & 0.83 & 3.00 \\
\hline $\begin{array}{l}\text { 17.İşletme ve çevre arasındaki ilişki yeşil muhasebe uygulamaları ile } \\
\text { raporlanır. }\end{array}$ & 18 & 6.1 & 55 & 18.5 & 116 & 39.1 & 108 & 36.4 & 3.05 & 0.88 & 3.00 \\
\hline
\end{tabular}

Selçuk Üniversitesi Sosyal Bilimler Meslek Yüksekokulu Dergisi, Yıl: 2020 Cilt: 23 Sayı:1 


\begin{tabular}{|c|c|c|c|c|c|c|c|c|c|c|c|}
\hline 18.İşletmeler çevresel performanslarını raporlamalıdır. & 17 & 5.7 & 33 & 11.1 & 111 & 37.4 & 136 & 45.8 & 3.23 & 0.86 & 3.00 \\
\hline $\begin{array}{l}\text { 19.İ̧sletmelerin yeşil muhasebe uygulamalarına katılmaları devlet tarafından } \\
\text { zorunlu hale getirilmelidir. }\end{array}$ & 14 & 4.7 & 55 & 18.5 & 116 & 39.1 & 112 & 37.7 & 3.09 & 0.86 & 3.00 \\
\hline $\begin{array}{l}\text { 20.Yeşil muhasebe uygulamaları dolaylı olarak işletmelerin maliyetlerinin } \\
\text { düşmesini sağlar. }\end{array}$ & 17 & 5.7 & 54 & 18.2 & 127 & 42.8 & 99 & 33.3 & 3.03 & 0.86 & 3.00 \\
\hline 21.Etrafımdaki insanları çevreye zarar vermemeleri konusunda uyarırım. & 18 & 6.1 & 21 & 7.1 & 102 & 34.3 & 156 & 52.5 & 3.33 & 0.85 & 4.00 \\
\hline 22.Geri dönüşümlü ürünleri pahalı olsa da alırım. & 32 & 10.8 & 74 & 24.9 & 144 & 48.5 & 47 & 15.8 & 2.69 & 0.86 & 3.00 \\
\hline 23.Ozon tabakasına zarar veren ürünleri kullanmam. & 26 & 8.8 & 70 & 23.6 & 100 & 33.7 & 101 & 34 & 2.92 & 0.96 & 3.00 \\
\hline $\begin{array}{l}\text { 24.Çevreyi korumak için elektrik, su ve yakıt tüketimini azaltmaya dikkat } \\
\text { ederim. }\end{array}$ & 15 & 5.1 & 39 & 13.1 & 120 & 40.4 & 123 & 41.4 & 3.18 & 0.84 & 3.00 \\
\hline $\begin{array}{l}\text { 25.İki çeşit ürün arasında seçim yaparken çevreye en az zarar veren ürünü } \\
\text { satın almayı tercih ederim. }\end{array}$ & 24 & 8.1 & 49 & 16.5 & 130 & 43.8 & 94 & 31.6 & 2.98 & 0.89 & 3.00 \\
\hline
\end{tabular}

Tablo 5 incelendiğinde katılımcıların Yeşil Muhasebe Algıı ve Farkındalık ölçeğinde bulunan sorulara verdikleri cevapların ortalamaları saptandı. Katılımcıların ölçek sorularına verdikleri cevapların ortalamalarına bakıldığında en yüksek ortalamaya sahip "Etrafımdaki insanları çevreye zarar vermemeleri konusunda

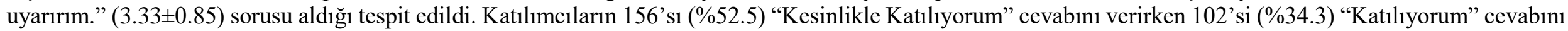
vermiştir. Ortalamalardan yola çıkarak katılımcıların bu ifadeye karşı algı ve farkındalıklarının yüksek olduğu ifade edilebilir. En düşük ortalamayı ise "Yeşil

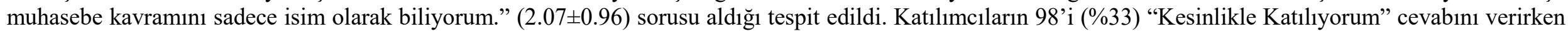
110 'u (\%37) "Katılıyorum" cevabını vermiştir. Ortalamalardan yola çıkarak katılımcıların 208'i (\%70) yeşil muhasebe konusunu sadece isim olarak bildiği ve bu konudaki bilgi düzeylerinin düşük olduğu ifade edilebilir. 
Tablo 6 Yeşil Muhasebe Toplam Ölçek ve Boyut Ortalamaları

\begin{tabular}{lccccc}
\hline \multicolumn{1}{c}{ Ölçek Boyutları } & Ortalama $\overline{\boldsymbol{X}}$ & S.S & Medyan & Max & Min \\
\hline Yeşil Muhasebe AIgısı & $\mathbf{3 . 1 1}$ & 0.59 & 3.10 & 4.00 & 1.10 \\
Çevre Bilinci & $\mathbf{2 . 3 8}$ & 0.52 & 2.50 & 4.00 & 1.00 \\
Yeşil Muhasebe Eğitimi & 3.08 & 0.75 & 3.00 & 4.00 & 1.00 \\
Yeşil Muhasebe Farkındalığı & 2.88 & 0.58 & 3.00 & 4.00 & 1.00 \\
Toplam Ölçek & 2.95 & 0.50 & 3.00 & 3.88 & 1.08 \\
\hline
\end{tabular}

Tablo 6 incelendiğinde Yeşil Muhasebe Algı ve Farkındalık ölçeğinin ve ölçek boyutlarının ortalamalarına yer verilmiştir. Ortalamalar incelendiğinde "Yeşil Muhasebe Algısı" 3.11 \pm 0.59 , "Çevre Bilinci" 2.38 \pm 0.52 , "Yeşil Muhasebe Eğitimi" 3.08 \pm 0.75 ve son olarak "Yeşil Muhasebe Farkındalığı" $2.88 \pm 0.58$ olarak tespit edilmiştir. Ortalamalardan yola çıkarak katılımcıların "Yeşil Muhasebe Algısı" boyutuna ait algı ve farkındalıklarının yüksek olduğu "Çevre Bilinci" boyutuna ait ifadelere karşı ise algı ve farkındalıklarının düşük olduğu ifade edilebir.

Tablo 7 Yeşil Muhasebe Ölçeğinin İki Değişkenli İfadelerle Karşılaştırılması

\begin{tabular}{|c|c|c|c|c|}
\hline Değişkenler & $\mathbf{N}(297)$ & $\bar{x}$ & SS & Test Değerleri \\
\hline \multicolumn{5}{|l|}{ Cinsiyet } \\
\hline Erkek & 122 & 2.98 & 0.51 & \multirow{2}{*}{$\begin{array}{c}\mathrm{U}=9862.500 \\
\mathrm{p}=0.264\end{array}$} \\
\hline Kadın & 175 & 2.92 & 0.50 & \\
\hline \multicolumn{5}{|l|}{ Bölüm } \\
\hline Sağlık Yönetimi & 183 & 2.81 & 0.44 & \multirow{2}{*}{$\begin{array}{c}\mathrm{U}=5086.500 \\
\mathbf{p}=\mathbf{0 . 0 0 0}\end{array}$} \\
\hline İşletme & 114 & 3.17 & 0.52 & \\
\hline \multicolumn{5}{|l|}{ Öğretim Türü } \\
\hline Normal Öğretim & 155 & 2.89 & 0.55 & \multirow{2}{*}{$\begin{array}{c}\mathrm{U}=9776.500 \\
\mathrm{p}=0.096\end{array}$} \\
\hline İkinci Öğretim & 142 & 3.01 & 0.44 & \\
\hline \multicolumn{5}{|c|}{$\begin{array}{l}\text { Muhasebe Alanında Staj } \\
\text { veya İş Tecrübesi }\end{array}$} \\
\hline Evet & 90 & 3.05 & 0.57 & \multirow{2}{*}{$\begin{array}{c}U=7010.000 \\
\mathbf{p}=\mathbf{0 . 0 0 1}\end{array}$} \\
\hline Hayır & 207 & 2.90 & 0.46 & \\
\hline
\end{tabular}

İşletme ve Sağlık Yönetimi öğrencilerinin Yeşil Muhasebe Konusundaki Algı ve Farkındalıkları demografik değişkenlere göre incelendiğinde; cinsiyet $(p=0.264 \mathrm{U}=9862.500)$ ve öğrenim türü $(p=0.096$ $\mathrm{U}=9776.500$ ) değişkenleri ile Yeşil Muhasebe Konusundaki Algı ve Farkındalıkları arasında istatistiksel olarak anlamlılık tespit edilememiştir $(\mathrm{p}>0.05)$. Bölüm değişkeni ile Yeşil Muhasebe Konusundaki Alg1 ve Farkındalıkları arasındaki ilişki incelendiğinde aralarında istatistiksel olarak anlamlılık tespit edilmiştir $(\mathrm{p}=0.000 \mathrm{U}=5086.500)$. Ortalamalar incelendiğinde işletme bölümü öğrencilerinin $3.17 \pm 0,52$ sağlık yönetimi bölümü öğrencilerinin $2.81 \pm 0,44$ olduğu ve işletme bölümü öğrencilerinin sağlık yönetimi bölümü öğrencilerine göre yeşil muhasebe konusundaki algı ve farkındalıklarının daha yüksek olduğu ifade edilebilir. Muhasebe alanında staj veya iş tecrübesi değişkeni ile Yeşil Muhasebe Konusundaki Algı ve Farkındalıkları arasındaki ilişki incelendiğinde aralarında istatistiksel olarak anlamlılık tespit edilmiştir $(\mathrm{p}=0.001$ $\mathrm{U}=7010.000$ ). Ortalamalar incelendiğinde staj deneyimi olan öğrencilerin $3.05 \pm 0,57$ staj deneyimi olmayan öğrencilerin $2.90 \pm 0.46$ olduğu ve staj deneyimi olan öğrencilerin olmayan öğrencilere göre yeşil muhasebe konusundaki algı ve farkındalıklarının daha yüksek olduğu ifade edilebilir.

Tablo 8 Yeşil Muhasebe Ölçeğinin İkiden Fazla Değişkenli İfadelerle Karşılaştırılması

\begin{tabular}{lcccc}
\hline Değişkenler & N (297) & $\overline{\boldsymbol{x}}$ & SS & Test Değerleri \\
\hline Yaş & & & & \\
20 ve Altı* & 102 & 2.90 & 0.44 & KW=10.016 \\
21-24 Arası & 171 & 2.95 & 0.52 & $\mathbf{p = 0 . 0 0 7}$ \\
25 ve Üstü* & 24 & 3.17 & 0.58 & \\
\hline Sinıf & & & & \\
1.Sinıf* & 88 & 2.86 & 0.54 & \\
2.Sinıf & 109 & 2.99 & 0.43 & KW=17.421 \\
3.Sinıf* & 61 & 2.86 & 0.50 & $\mathbf{p = 0 . 0 0 1}$ \\
4.Sınıf* & 39 & 3.17 & 0.54 & \\
\hline
\end{tabular}




\begin{tabular}{|c|c|c|c|c|}
\hline \multicolumn{5}{|l|}{ Akademik Ortalama } \\
\hline $1,00-1,50 *$ & 14 & 2.73 & 0.48 & \multirow{6}{*}{$\begin{array}{c}\mathrm{KW}=12.175 \\
\mathbf{p}=\mathbf{0 . 0 3 2}\end{array}$} \\
\hline $1,51-2,00$ & 61 & 2.92 & 0.47 & \\
\hline $2,01-2,50$ & 89 & 2.87 & 0.50 & \\
\hline $2,51-3,00 *$ & 81 & 3.07 & 0.45 & \\
\hline $\mathbf{3 , 0 1 - 3 , 5 0}$ & 38 & 2.95 & 0.58 & \\
\hline $3,51-4,00 *$ & 14 & 3.02 & 0.66 & \\
\hline \multicolumn{5}{|l|}{ Aldığınız Muhasebe Dersi } \\
\hline Genel Muhasebe & 297 & 3.11 & 0.51 & \multirow{5}{*}{$\begin{array}{c}\mathrm{KW}=0.211 \\
\mathrm{p}=0.646\end{array}$} \\
\hline Yönetim Muhasebesi & 102 & 3.02 & 0.50 & \\
\hline Finansal Yönetim & 209 & 3.01 & 0.50 & \\
\hline Maliyet Muhasebesi & 102 & 3.08 & 0.55 & \\
\hline Diğer & 127 & 3.20 & 0.42 & \\
\hline \multicolumn{5}{|l|}{ Mezun Olduktan Sonra } \\
\hline \multicolumn{5}{|l|}{ Yapmayı Düşündüğünüz Meslek } \\
\hline Akademisyenlik & 52 & 2.92 & 0.53 & \multirow{7}{*}{$\begin{array}{c}\mathrm{KW}=33.149 \\
\mathbf{p}=\mathbf{0 . 0 0 0}\end{array}$} \\
\hline Mali Müşavirlik-Muhasebecilik* & 37 & 3.25 & 0.48 & \\
\hline Bankacılık & 16 & 3.23 & 0.41 & \\
\hline Özel Sektörde İdari Görev* & 72 & 2.92 & 0.43 & \\
\hline Devlet Kurumlarında Uzmanlık* & 35 & 2.80 & 0.54 & \\
\hline Memurluk* & 40 & 2.86 & 0.60 & \\
\hline Diğer* & 45 & 2.87 & 0.40 & \\
\hline
\end{tabular}

İşletme ve Sağlık Yönetimi öğrencilerinin Yeşil Muhasebe Konusundaki Alg1 ve Farkındalıkları demografik değişkenlere göre incelendiğinde; aldığınız muhasebe dersi $(p=0.646 \mathrm{KW}=0.211)$ değişkeni ile Yeşil Muhasebe Konusundaki Alg1 ve Farkındalıkları arasında istatistiksel olarak anlamlılık tespit edilememiştir ( $\mathrm{p}>0.05)$. Yaş değişkeni ile Yeşil Muhasebe Konusundaki Alg1 ve Farkındalıkları arasındaki ilişki incelendiğinde aralarında istatistiksel olarak anlamlılık tespit edilmiştir $(\mathrm{p}=0.007 \mathrm{KW}=10.016)$. Tamhane T2 testine göre bu anlamlılık 20 ve alt1 yaş $(\bar{X}=2.90 \pm 0.44)$ grubunda bulunan öğrenciler ile 25 ve üstü yaş $(\bar{X}=3.17 \pm 0.58)$ grubunda bulunan öğrenciler arasındaki farklılıktan olduğu belirlenmiştir. Buna göre ortalamalara bakıldığında yaşı daha büyük öğrencilerin yeşil muhasebe konusundaki algı ve farkındalıklarının yaşı küçük olan öğrencilere göre daha yüksek olduğu ifade edilebilir. Sınıf değişkeni ile Yeşil Muhasebe Konusundaki Algı ve Farkındalıkları arasındaki ilişki incelendiğinde aralarında istatistiksel olarak anlamlılık tespit edilmiştir ( $\mathrm{p}=0.001 \mathrm{KW}=17.421)$. Tamhane $\mathrm{T} 2$ testine göre bu anlamlılık 1 . $\sin 1 \mathrm{f}(\bar{X}=2.86 \pm 0.44)$ ve 3 . sinıfta $(\bar{X}=2.86 \pm 0.50)$ eğitim gören ögrenciler ile 4 . sinıfta $(\bar{X}=3.17 \pm 0.54)$ eğitim gören öğrenciler arasındaki farklılıktan olduğu belirlenmiştir. Buna göre son sınıf öğrencilerinin birinci ve üçüncü sınıfta eğitim gören öğrencilere göre yeşil muhasebe konusundaki algı ve farkındalıklarının daha yüksek olduğu ifade edilebilir. Akademik ortalama değişkeni ile Yeşil Muhasebe Konusundaki Alg1 ve Farkındalıkları arasındaki ilişki incelendiğinde aralarında istatistiksel olarak anlamlılık tespit edilmiştir $(\mathrm{p}=0.032 \mathrm{KW}=12.175)$. Tamhane T2 testine göre bu anlaml1lik $2,51-3,00$ not ortalamas1 $(\bar{X}=3.07 \pm 0.45)$ ve $3,51-4,00$ not ortalamasina $(\bar{X}=3.02 \pm 0.66)$ sahip öğrenciler ile $1,00-1,50$ not ortalamasına $(\bar{X}=3.73 \pm 0.48)$ sahip öğrenciler arasındaki farkl1lıktan olduğu belirlenmiştir. Buna göre not ortalaması yüksek olan öğrencilerin yeşil muhasebe konusundaki algı ve farkındalıklarının not ortalaması düşük olan öğrencilere göre daha yüksek olduğu ifade edilebilir. Son olarak öğrencilerin mezun olduktan sonra yapmayı düşündüğü meslek değişkeni ile Yeşil Muhasebe Konusundaki Algı ve Farkındalıkları arasındaki ilişki incelendiğinde aralarında istatistiksel olarak anlamll1ık tespit edilmiştir $(\mathrm{p}=0.000 \mathrm{KW}=33.149)$. Tamhane $\mathrm{T} 2$ testine göre bu anlamlılık özel sektörde idari görev $(\bar{X}=2.92 \pm 0.43)$, devlet kurumlarında uzmanlık $(\bar{X}=2.80 \pm 0.54)$, memurluk $(\bar{X}=2.86 \pm 0.60)$ ve diğer seçenekli $(\bar{X}=2.87 \pm 0.40)$ meslekler ile mali müşavirlik-muhasebecilik $(\bar{X}=3.25 \pm 0.48)$ mesleği arasındaki farklılıktan olduğu belirlenmiştir. Buna göre mezun olduktan sonra mali müşavirlik veya muhasebecilik yapmak isteyen öğrencilerin diğer meslek dallarına göre yeşil muhasebe konusundaki algı ve farkındalıklarının daha yüksek olduğu ifade edilebilir.

\section{SONUÇ VE ÖNERILER}

$\mathrm{Bu}$ çalışma, işletme ve sağlık yönetimi bölümü lisans öğrencilerinin yeşil muhasebe konusundaki alg1 ve farkındalıklarını belirlemek amacıyla yapılmıştır. Bu amaçla Erzincan Binali Yıldırım Üniversitesi İktisadi ve İdari Bilimler Fakültesinde eğitim gören işletme ve sağlık yönetimi bölümü öğrencilerinin yeşil muhasebe algıları ve farkındalıkları belirlenmiştir. Ayrıca yeşil muhasebe algı ve farkındalık düzeyinin demografik 
değişkenlere göre farklılaşıp farklılaşmadığı tespit edilmiştir. Öğrencilere yapılan anket çalışmasının sonuçları hipotez sınamaları ile birlikte aşağıda verilmiştir.

Çalışmada öncelikle demografik durumlar incelendiğinde öğrencilerin "Muhasebe alanında staj veya iş tecrübesi var mı?" sorusuna çoğunluğun hayır cevabı verdiği belirlenmiştir. Ayrıca her iki bölümde de eğitim gören öğrencilerin genel muhasebe, finansal yönetim, yönetim muhasebesi ve maliyet muhasebesi derslerini aldıkları tespit edildi. Demografik değişkenlerden son olarak öğrencilere “ Mezun olduktan sonra yapmayı düşündüğünüz meslek" sorulduğunda sırasıyla özel sektörde idari görev, akademisyenlik, diğer, memurluk, mali müşavirlik-muhasebecilik, devlet kurumlarında uzmanlık, bankacılık meslekleri geldiği belirlenmiştir. Sonuçlar incelendiğinde öğrencilerin büyük bir çoğunluğunun mali müşavirlik-muhasebecilik mesleğini ilk tercih olarak seçmediği görülmüştür.

Öğrencilerin ölçek sorularına verdikleri olumlu cevaplar incelendiğinde "Etrafımdaki insanları çevreye zarar vermemeleri konusunda uyarırım" sorusuna kesinlikle katıldıkları ve öğrencilerin çevreye karşı alg1 ve farkındalıklarının yüksek olduğu görülmüştür. Ayrıca sırası ile "İşletmeler çevresel performanslarını raporlamalıdır" ve "Yeşil muhasebe uygulamalarının temiz ve güvenli üretimi arttıracağına inanıyorum" sorularına da yüksek oranda katıldıkları tespit edilmiştir. Öğrenciler işletmelerin çevresel faaliyetlerinin raporlanmas1, düzenlenmesi, kaydedilmesi ve yorumlanması gibi faaliyetlere önem verdiği görülmüştür. Son olarak öğrencilerin büyük bir çoğunluğu yeşil muhasebe uygulamaları ile temiz ve güvenli üretim yapılacağına inandıkları tespit edilmiştir.

Öğrencilerin ölçek sorularına verdikleri olumsuz cevaplar incelendiğinde "Eğitimim sırasında yeşil muhasebe ile ilgili ders aldım" sorusuna kesinlikle katılmadıkları ve öğrencilerin büyük bir çoğunluğunun lisans eğitimi boyunca yeşil muhasebe konsunda eğitim almadığı görülmüştür. Ayrıca sırası ile "Yeşil muhasebe kavramını sadece isim olarak biliyorum" ve "Yeşil muhasebenin ne olduğu konusunda hiçbir bilgi sahibi değilim" sorularına da katılmadıkları tespit edilmiştir. Öğrenciler lisans eğitimi boyunca aldıkları genel muhasebe, finansal yönetim, yönetim muhasebesi ve maliyet muhasebesi gibi derslerde yeşil muhasebe konusunu sadece isim olarak bildikleri ya da yeşil muhasebe konusunda bilgi sahibi olmadıkları görülmüştür.

Öğrencilerin yeşil muhasebe konusundaki algı ve farkındalıkları ile demografik değişkenler arasında anlamlı bir fark olup olmadığına ilişkin olarak oluşturulan hipotezlerin sonuçları aşağıdaki gibidir.

Yeşil muhasebe konusundaki algı ve farkındalık ölçeğinin iki ve üç değiş̧kenli ifadelerle karşılaştırılması sonucunda elde edilen sonuçlar incelendiğinde $\mathrm{H}_{2}, \mathrm{H}_{4}$ ve $\mathrm{H}_{8}$ hipotezleri 0.05 anlamlılık düzeyinde reddedilmiştir. Söz konusu değişkenler ile öğrencilerin yeşil muhasebe konusundaki algı ve farkındalıkları arasında anlamlı bir ilişkiye rastlanmamıştır. Buna göre öğrencilerin cinsiyetleri (Erkek- Bayan), öğrenim türleri (Normal-İkinci Öğretim) ve lisans eğitimleri boyunca aldıkları muhasebe dersleri (Genel MuhasebeYönetim Muhasebesi- Finansal Yönetim- Maliyet Muhasebesi- Diğer) yeşil muhasebe konusundaki alg1 ve farkındalıkları üzerinde bir etkisi olmadığı görülmüştür.

Çalışmanın metodoloji kısmında oluşturduğumuz $\mathrm{H}_{1}, \mathrm{H}_{3}, \mathrm{H}_{5}, \mathrm{H}_{6}, \mathrm{H}_{7}$ ve $\mathrm{H}_{9}$ hipotezleri ise 0.05 anlamlılık düzeyinde kabul edildi. Söz konusu değişkenler ile öğrencilerin yeşil muhasebe algı ve farkındalıkları arasında anlamlı bir ilişkiye rastlanmıştır. Buna göre;

- $\quad$ işletme bölümü öğrencilerinin sağllk yönetimi bölümü öğrencilerine göre yeşil muhasebe konusundaki alg1 ve farkındalıklarının daha yüksek olduğu,

- $\quad$ staj deneyimi olan öğrencilerin olmayan öğrencilere göre yeşil muhasebe konusundaki alg1 ve farkındalıklarının daha yüksek olduğu,

- $\quad$ yaşı daha büyük öğrencilerin yeşil muhasebe konusundaki algı ve farkındalıklarının yaşı küçük olan öğrencilere göre daha yüksek olduğu,

- $\quad$ son sınıf öğrencilerinin birinci ve üçüncü sınıfta eğitim gören öğrencilere göre yeşil muhasebe konusundaki algı ve farkındalıklarının daha yüksek olduğu,

- $\quad$ not ortalaması yüksek olan öğrencilerin yeşil muhasebe konusundaki algı ve farkındalıklarının not ortalaması düşük olan öğrencilere göre daha yüksek olduğu,

- mezun olduktan sonra mali müşavirlik veya muhasebecilik yapmak isteyen öğrencilerin diğer meslek dallarına göre yeşil muhasebe konusundaki algı ve farkındalıklarının daha yüksek olduğu görülmüştür.

Sonuç olarak; öğrencilerin yeşil muhasebe konusundaki algı ve farkındalıkları incelendiğinde sağlık yönetimi ve işletme bölümü öğrencileri arasında fark olduğu söylenebilir. $\mathrm{Bu}$ farkın işletme bölüm öğrencilerinin sağlık yönetimi bölümü öğrencilerine göre daha fazla ve çeşitte muhasebe dersleri almasından kaynaklandığ 1 düşünülmektedir. Bu açıdan muhasebe derslerinin sayısı ve içeriği yeşil muhasebe konusunda bir algı ve farkındalık yarattığı için bu derslerde yeşil muhasebe konusuna ayrı önem verilmesi gerekmektedir. Ayrıca öğrencilerin lisans eğitimleri boyunca muhasebe alanında staj veya iş durumları incelendiğinde 
muhasebe alanında staj yapan veya çalışan öğrencilerin yeşil muhasebe algı ve farkındalıklarının arttı̆g 1 sonucuna ulaşılmıştır. Bu sebeple öğrencilerin lisans dönemlerinde muhasebe alanında staj yapmaları veya muhasebe alanında herhangi bir iş tecrübesine sahip olmalarıyla birlikte yeşil muhasebe konusundaki bilgi düzeylerinin arttırılabileceği düşünülmektedir.

Son olarak sürdürülebilir kalkınma, daha yaşanılabilir çevre, temiz üretim ve günümüzdeki kaynakların gelecek nesillere aktarılmasında en önemli rolü oynayacak ve geleceğin işletmecisi, yöneticisi veya muhasebecisi olmaya aday üniversite öğrencilerinin lisans eğitimleri boyunca yeşil muhasebe konusunda bilgi düzeylerinin, algılarının ve farkındalıklarının arttıılması gerekmektedir. Çevreye daha duyarlı öğrenciler yetiştirebilmek için muhasebe dersleri kapsamında yeşil muhasebe ya da çevre muhasebesi alanlarında gerekli eğitimlerin verilmesi elzemdir. 


\section{KAYNAKÇA}

Aktürk, A., Akcanlı, F., Şenol, H., \& Akyüz, Y. (2012). Muhasebe Standartları Bağlamında Otel İşletmelerinde Çevre Muhasebesi. Ekonomik ve Sosyal Araştırmalar Dergisi.

Alagöz, A. \& Yılmaz, B. (2001). Çevre Muhasebesi ve Çevresel Maliyetler. Selçuk Üniversitesi İktisadi ve İdari Bilimler Fakültesi Sosyal ve Ekonomik Araştırmalar Dergisi, 1 (1-2), Nisan-Ekim, 147-158.

Alkan, F. K. A. B. A., Kurşunel, F., \& Alkan, A. T. (2006). Muhasebe Meslek Mensuplarının Çevre Muhasebesi Hakkındaki Görüşleri: Konya İli Üzerine Bir Araştırma. Karamanoğlu Mehmetbey Üniversitesi Sosyal ve Ekonomik Araştırmalar Dergisi, 2006 (2), 82-88.

Antepli, A. \& Aslan, Ş. (2018). Yeşil Muhasebe ve Çevresel Maliyetlerin Hesaplanması. Journal of Social And Humanities Sciences Research, 5 (24), 1459-1467.

Aronsson, T., \& Löfgren, K. G. (1998). Green Accounting in Imperfect Market Economies. Environmental and Resource Economics, 11 (3-4), 273-287.

Aslanertik, B. E., \& Özgen, I. (2007). Otel İşletmelerinde Çevresel Muhasebe. Dokuz Eylül Üniversitesi İşletme Fakültesi Dergisi, 8 (2), 163-179.

Bengü, H., \& Can, A. V. (2009). Çevre Muhasebesinin Muhasebenin Temel Kavramlarından "Sosyal Sorumluluk Kavramı” Bağlamında Temellendirilmesi. Celal Bayar Üniversitesi Sosyal Bilimler Enstitüsü Dergisi, 7(1), 155160.

Bezirci, M., Özpeynirci, R., \& Durman, H. (2011). Sosyal Sorumluluk Kavramı Bağlamında Yeşil Muhasebe Eğitimi: Bir Alan Araştırması.

Cairns, R. D. (2001). Seeing The Trees As A Forest: What Counts In Green Accounting. Ecological Economics, 36 (1), 61-69.

Cairns, R. D. (2004). Principles Of Green Accounting For Renewable And Nonrenewable Energy Resources. Energy Policy, 32(2), 261-267.

Cairns, R. D. (2009). Green Accounting For Black Gold. The Energy Journal, 113-139.

Clarke, K., O'neill, S (2005). Is The Environmental Professional....An Accountant? Gm1. 49. (2005): 111-124.

Esmeray, M., \& Güngör Tanç, Ş. (2009). Çevresel Maliyetlerin Mamullere Yüklenmesinde Kullanılan Dağıtım Anahtarlarının Seçiminde Analitik Hiyerarşi Yöntemi ve Bir Uygulama. Süleyman Demirel Üniversitesi İktisadi ve İdari Bilimler Fakültesi Dergisi, 14(2), 241-260.

Fleischman, R. K. \& Schuele, K. (2006). Green Accounting: A Primer. Journal of Accounting Education, 24 (1), 35-66.

Haftacı, V., \& Soylu, K. (2007). Çevre Kirlenmesi Ve Çevre Koruma Bağlamında Çevre Muhasebesinin Önemi. Muhasebe Ve Finansman Dergisi, (33), 102-120.

Halberg, N.,Verschuur, G. \& Goodlass, G. (2005). Farm Level Environmental Indicators; Are They Useful?: An Overview Of Green Accounting Systems For European Farms.Agriculture, Ecosystems \& Environment,105 (1), 195-212.

Kılıç, S. (2012). Örnek Büyüklüğü, Güç Kavramları Ve Örnek Büyüklüğü Hesaplaması. Journal Of Mood Disorders, 2(3), 140-2.

Kırlığlu, H., \& Can, A. V. (2006). Çevresel Muhasebede Kavramsal Tartı̧̧aların Gelişimi ve Analizi. Muhasebe ve Finansman Dergisi, (32), 1-12.

Korukoğlu, A. (2011). İşletmelerde Çevre Muhasebesi: İzmir İli Uygulaması. Ege Akademik Bakış Dergisi, 11 (1), 81 89.

Memiş, M. Ü. (2009). İşletme Yönetim Aracı Olarak Çevresel Muhasebe. Çukurova Üniversitesi İktisadi ve İdari Bilimler Fakültesi Dergisi, 13 (1), 89-106.

Özbirecikli, M. \& Melek, Z. (2002). "Çevre Muhasebesi ve Çevresel Maliyetlerin Maliyet Muhasebesi Sistemine Etkileri ve Bir Araştırma", Muhasebe ve Finansman Dergisi, 14, 85 - 90.

Özkol, A. E. (1998), Çevre Muhasebesi, İktisadi ve İdari Bilimler Fakültesi Dergisi, 13 (1), 15-26.

Sevilengül, O. (2005). Genel Muhasebe. Ankara: Gazi Kitabevi.

Tansel Çetin, A., Özcan, M. \& Yücel, R. (2004). Çevre Muhasebesine Genel Bakış. Sosyal Ekonomik Araştırmalar Dergisi, 7: 61-76.

Vincent, J. R. (2000). Green Accounting: From Theory To Practice. Environment And Development Economics, 5 (1), $13-24$.

Yılmaz, Z., \& Şahin, Z. (2017). Muhasebe Dersi Alan Öğrencilerin Yeşil Muhasebe Konusundaki Algıları Ve Farkındalıkları. Balkan ve Yakın Doğu Sosyal Bilimler Dergisi, 3 (01), 110-122.

Yousef F. J. (2003) "Green Accounting In Developing Countries: The Case of U.A.E. And Jordan", Managerial Finance, $29(8), 37-45$. 